\title{
Entrepreneurial intentions of students in a historically disadvantaged university in South Africa
}

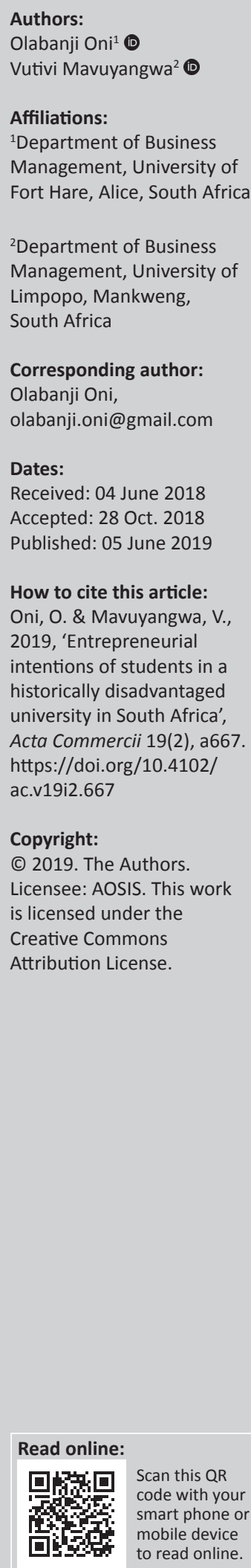

Orientation: The entrepreneurial intentions of students in different faculties of a historically disadvantaged university in South Africa are not known and are not measured.

Research purpose: The purpose of this study was to assess the entrepreneurial intentions of students in a historically disadvantaged university in South Africa. This study was based on two objectives, namely, to determine the entrepreneurial intention of students in four different faculties in a historically disadvantaged South African university and to assess if significant differences exist between entrepreneurial intentions of students in the four different faculties of a historically disadvantaged South African university.

Motivation for the study: Graduate unemployment is on the rise in South Africa. Furthermore, the entrepreneurial intentions of students across faculties in historically disadvantaged institutions are underexplored and needs further testing. This study aims to assess the entrepreneurial intentions of students in a historically disadvantaged university in South Africa.

Research design, approach and method: Quantitative research was utilised and 377 students from a historically disadvantaged South African university were surveyed. Simple random sampling technique was utilised in the study. Reliability was measured using Cronbach's alpha. Mean, standard deviation and Chi-square test were utilised in the data analysis.

Main findings: The findings revealed that significant differences exist between the entrepreneurial intentions of students in the four different faculties (health sciences, management and law, humanities as well as science and agriculture). The study also found that the students in the Faculty of Management and Law have a high entrepreneurial intentions. The study focused on one historically disadvantaged university in South Africa; therefore, the findings of this study should be interpreted cautiously for other universities in South Africa. Future research can be replicated in other South African universities.

Practical/managerial implications: The findings of this study have implications to policymakers in higher education and lecturers in South Africa universities. This study recommends entrepreneurial education courses for all students in the universities and policy decisions that allow students to start businesses. This is expected to promote entrepreneurship, employment and economic development in South Africa.

Contribution/value-add: The novelty of this study is the contribution to the body of knowledge on entrepreneurial intentions of university students across faculties in South Africa. In addition, studies on entrepreneurial intentions of students from historically disadvantaged universities are underexplored. The study provides useful recommendations on entrepreneurial intention of South African students from a historically disadvantaged university.

Keywords: entrepreneurial intentions; university students; historically disadvantaged universities; entrepreneurship; South Africa.

\section{Introduction}

Over the last 10 years, scholars have extensively debated the issue of entrepreneurial intentions of students in higher education. The entrepreneurial intentions are defined as a proportion of the economic active population that would like to begin an enterprise in 3 years (Global Entrepreneurship Monitor 2018). Individuals with intent to start an enterprise are very likely to start, and it is sensible to recommend that investigating entrepreneurial intentions is an important method to learning actual entrepreneurial behaviour (Zhang, Wang \& Owen 2015). The most successful countries in the world are the ones with high entrepreneurship intentions and activities. Therefore, entrepreneurship can be used as a tool to navigate unemployment and stimulate growth in 
the economy. Entrepreneurship contributes to the prosperity of today's society. Entrepreneurship drives innovation, employment, competition, economic growth and development (Mganda 2018; Tomkins 2012). In addition, most academics and policy-makers agree that entrepreneurship is essential for the improvement and welfare of the people (Saroghi, Libaers \& Burkemper 2015). In fact, for example, various universities such as University of Western Cape, University of Cape Town, University of Witwatersrand, Vaal University of Technology and North West University in South Africa have included entrepreneurship as their niche area and have established centres of entrepreneurship and innovation. In addition, the Department of Higher Education and Training in 2017 introduced the Entrepreneurship Development in Higher Education (EDHE) Programme to develop and increase entrepreneurship of students in South African universities. A budget of R17.9 million was allocated for EDHE programme over the period 2017/18-2019/20 (Department of Higher Education and Training 2018).

Notwithstanding, Global Entrepreneurship Monitor report (2018) stated that South Africa is ranked 39 out of the 54 countries surveyed by the Global Entrepreneurship Monitor (GEM) in 2017 on the self-perception of entrepreneurship based on the entrepreneurial intention criterion. Although South Africa recorded an increase in total entrepreneurial activity (TEA) from $6.9 \%$ in 2016 to $11.0 \%$ in 2017, this increase is still lower than the mean TEA rate of $16.4 \%$ for other efficiency-driven countries in 2017 (Global Entrepreneurship Monitor 2018). Extantstudies reported that the entrepreneurial intentions of students are low in South Africa and South African universities (Fatoki \& Chidonga 2011; Herrington \& Kew 2016; Madzivhandila \& Dlamini 2015; Odora 2015; Scheepers, Solomon \& de Vries 2009). In addition, the GEM report (2018) pointed out that South Africa is ranked 38 out of 54 countries on the entrepreneurial education at the school stage and 45 out of 54 on the entrepreneurial education at the post-school stage. These ranking positions of South Africa on entrepreneurial education are alarming and worrying. Furthermore, Statistics South Africa (2018b) reported that the unemployment rate in South in the second quarter of 2018 recorded $27.2 \%$. 'The graduate unemployment rate in South Africa recorded a high rate of $11.9 \%$ in the second quarter of 2018' (Statistics South Africa 2018a).

Various empirical studies have highlighted the importance of entrepreneurial intentions (Aulia \& Hadi 2018;Barral, Ribeiro \& Canener 2018; Ozaralli \& Rivenburgh 2016; Palmer et al. 2015; Zhang et al. 2015) and the intentions of students in universities to start businesses (Fayolle \& Gailly 2015; Shinnar, Giacomin \& Janssen 2012; Ubierna, Arranz \& Arroyabe 2014). Little attention has been placed on the entrepreneurial intention of students in historically disadvantaged universities according to their different faculties. Aulia and Hadi (2018) pointed out that despite the growing debate on entrepreneurial intentions, studies fall short in addressing the entrepreneurial intentions of students across faculties in institutions of higher education. This study seeks to fill this opening by investigating the entrepreneurial intentions of students in a historically disadvantaged university across four different faculties (health sciences, management and law, humanities as well as science and agriculture). The theory of planned behaviour is relevant for this study and is used to explain students' attitudes, subjective norms and perceived behavioural control. More details on this theory are provided in the theoretical review section. Hence, the aim of this study is to assess the entrepreneurial intentions of students in a historically disadvantaged university in South Africa. This study is guided by two objectives: firstly, to determine the entrepreneurial intention of students in four different faculties (health sciences, management and law, humanities as well as science and agriculture) in a historically disadvantaged South African university, and secondly, to assess if significant differences exist between entrepreneurial intentions of students in these faculties. The next section provides a discussion on the literature review.

\section{Literature review}

This section discusses the theoretical framework, the measurement of entrepreneurial intention and the factors affecting the entrepreneurial intentions of university students.

\section{Theoretical framework}

This study used the theory of planned behaviour to explain the students' intentions to start a business. Ajzen (1991) explained that attitudes, subjective norms and perceived behavioural control affect the intentions and behaviours of individuals. The theory of planned behaviour is relevant for this study because attitudes, subjective norms and perceived behavioural control are related to entrepreneurial intentions and behaviours of students in South African universities. The theory of planned behaviour explains entrepreneurial intentions based on attitudes, subjective norms and perceived behavioural control. For example, the following questions were applied to this study based on the three precursors of the theory of planned behaviour. Firstly, the subjective norm: subjective norms are the pressure applied by close people such as parents, friends, family and colleagues (Ajzen 1991; Fayolle \& Gailly 2015; Gerba 2012). Applying subjective norm to this study, the relevant question to be answered is: what is the influence of the university educators on university students in starting a business or becoming an entrepreneur? Secondly, attitude: attitudes are the beliefs of how the behaviour is perceived (Ajzen 1991). Applying attitudes to this study, the relevant question to be answered is: what are the student beliefs about starting their own businesses or becoming an entrepreneur? Thirdly, perceived behavioural control: perceived behavioural control is how easy or difficult it is in performing the behaviour (Ajzen 1991). Applying perceived behavioural control to this study, the relevant question to be answered is: how easy or difficult is it for university students to start their own businesses or be an entrepreneur? The next subsection provides a literature on entrepreneurial intentions. 


\section{Measurement of entrepreneurial intentions}

There is no one specific measurement for entrepreneurial intentions. Various measurements of entrepreneurial intentions have been provided by extant literature. Entrepreneurial intention can be measured using categorical and continuous methods. Fayolle and Liñán (2014) argued that entrepreneurship intention can be described in four different ways: family intention, academic intention, corporate intention and social intention. Liñán and Chen's (2009) six-point categorical statement was adopted for this study in measuring the entrepreneurial intentions of students in a disadvantaged South African university. Details of the six-point categorical statement are provided in the questionnaire construction. The next subsection provides a literature on the entrepreneurial intentions of university students.

\section{Entrepreneurial intentions of university students}

Various factors such as lack of employment among graduates, entrepreneurial education, demographic factors, previous work experience, attitude and skills among others can influence the entrepreneurial intentions of university students. To provide the best discussion, some of these factors will be discussed in this section. Obembe, Otesile and Ukpong (2014) as well as Pihie and Akmalia (2009) argued that lack of employment among graduates motivates entrepreneurial intentions and business start-ups. In addition, Fatoki (2014) found that business students' entrepreneurial intentions are higher than non-business students in a South African university because of entrepreneurial educational courses. Malebana and Swanepoel (2014) argued that entrepreneurial intentions of students are influenced by demographic factors. Iwu et al. (2016) found no significant relationship between demographic factors and entrepreneurial intentions of university students. Furthermore, Barral et al. (2018) found that private colleges have higher entrepreneurial intentions than public colleges because students in the private colleges have previous years' work experience. Zhang et al. (2015) believed that the different behaviours of university students are attributed to the lack of entrepreneurial experience. Levie, Hart and Anyadike-Danes (2009) argued that entrepreneurs with university degrees are more successful than those without university degrees. Aulia and Hadi (2018) found that a positive moderate nexus exists between attitude and entrepreneurial intentions of students in Indonesia. Pihie and Bagheri (2013) found a negative relationship between entrepreneurial skills and entrepreneurial intentions of students. This highlights the necessity and importance of identifying the entrepreneurial skills that improve students' entrepreneurial intentions. Although as explained in the first paragraph of this section that many factors influence the entrepreneurial intentions of students, it is important to highlight that each factor has its own merit and demerit in the context of higher education. There is an increasing interest in the intention of university scholars to start businesses. Aulia and Hadi (2018) explained that despite the growing debate on entrepreneurial intentions, limited studies have been conducted in higher education to investigate the entrepreneurial intentions of students across faculties in institutions of higher education. In addition, there are conflicting views on the factors that influence entrepreneurial intentions and the intentions of students in universities to start businesses (Fayolle \& Gailly 2015; Shinnar et al. 2012; Ubierna et al. 2014; Singh, Verma \& Rao 2017). The fact that there are limited studies on entrepreneurial intentions of students across faculties in universities and conflicting views on entrepreneurial intentions of students in universities necessitates this study. This study argues that significant differences exist between entrepreneurial intentions of students across faculties in a historically disadvantaged university in South Africa. This study hypothesises that:

$\mathbf{H}_{\mathbf{a}} \mathbf{1}$ : Significant differences exist between entrepreneurial intentions of students across four different faculties (health sciences, management and law, humanities as well as science and agriculture) in a historically disadvantaged university in South Africa.

\section{Research methods and design}

\section{Research design}

This study adopted descriptive research design because descriptive research design uses statistical methods to enquire about patterns (Feinberg, Kinear \& Tailor 2012). In addition, descriptive research was found to be appropriate for this study because this study used construct measurement and is quantitative in nature. The study tested if there are significant differences between entrepreneurial intentions of students across four different faculties (health sciences, management and law, humanities as well as science and agriculture) in a historically disadvantaged South African university.

\section{Study population and sampling strategy}

The target population for this study were all students in a historically disadvantaged university in South Africa with a population of 20004 students. This composed of 1403 students in the Faculty of Health Sciences, 6065 students in the Faculty of Management and Law, 6900 students in the Faculty of Humanities and 5636 students in the Faculty of Science and Agriculture. Four schools with the highest number of students were selected for each faculty, that is, in the Faculty of Health Sciences, the School of Health Sciences was selected, School of Economics and Management was selected for management and law, School of Education was selected for humanities and School of Molecular and Life Sciences was selected for science and agriculture. To ensure that every element selected has an equal chance of being drawn the simple random sampling technique was used. Raosoft online sample size calculator was used to calculate the sample size at $5 \%$ margin of error, confidence level of $95 \%$ and response distribution of $50 \%$. The minimum recommended sample size was 377 students. 


\section{Questionnaire construction}

Questions for entrepreneurial intention similar to the study of Liñán and Chen (2009) were adopted for this study. Section A covered the demographic information and section $B$ covered the six-point categorical statement adopted from Liñán and Chen (2009). These were (1) 'I am ready to do anything to become an entrepreneur'; (2) 'My professional goal is to become an entrepreneur'; (3) 'I will make every effort to start and run my own business'; (4) 'I am determined to create a business in the future'; (5) 'I have a serious thought of starting a business' and (6) 'I have got a firm intention to start a business someday'. All the six statements of entrepreneurial intentions recorded a Cronbach's alpha coefficient above 0.70; this shows that the scales are reliable for more analysis (see Table 1).

\section{Data collection}

The selected respondents were provided with questionnaires with close-ended questions to obtain information on the significant differences as set out in the hypothesis. A class list of the students was obtained from the assistant registrar of the four different faculties and students were randomly selected from the class list. The class list also allowed the researchers to identify the specific classes where the questionnaires could be distributed. The questionnaires were distributed in classes to the students by the researcher and research assistants.

\section{Data analysis}

The Statistical Package for Social Sciences (SPSS) version 24 software was used for the analysis. This study utilised descriptive statistics such as mean and standard deviation. The mean was used to measure the entrepreneurial intentions of the university students in the four different. Chi-square test was used to test for important differences in the level of entrepreneurial intentions in the four faculties. The next section provides an explanation on the results and discussion.

\section{Ethical considerations}

Permission was obtained from the university ethical research committee before commencing with the study. The respondents were informed about the aim and objectives of the study before the questionnaires were handed out. The confidentiality of the respondents was maintained. The researcher followed the principle of voluntary participation.

TABLE 1: Cronbach's alpha test.

\begin{tabular}{lc}
\hline Statement & Cronbach's alpha \\
\hline 'I am ready to do anything to become an entrepreneur' & 0.83 \\
'My professional goal is to become an entrepreneur' & 0.78 \\
'I will make every effort to start and run my own business' & 0.88 \\
'I am determined to create a business in the future' & 0.85 \\
'I have a serious thought of starting a-business' & 0.75 \\
'I have got a firm intention to start a business someday' & 0.89 \\
\hline
\end{tabular}

Source: Research Data 2018
The ethical permit number obtained for this study was ONI031SMAV01.

\section{Results and discussion}

\section{Response rate}

Three hundred and seventy-seven questionnaires were distributed in the lecture rooms by the researcher and research assistants and 364 were collected back from the students. This is a response rate of $97 \%$. Nine questionnaires were found not useful because the students did not complete all the relevant sections. Three hundred and fifty-five questionnaires were usable; 52\% (185) of respondents were male, while $48 \%$ (170) were female. The majority of the respondents were between the age group of 20-24 years.

Table 1 depicts the Cronbach's alpha test for all the six statements used in measuring the entrepreneurial intentions of students in the four different faculties of a South African university. All the statements of entrepreneurial intentions recorded a Cronbach's alpha coefficient above 0.70; this shows that the scales are reliable for more analysis.

Table 2 presents the descriptive statistics of entrepreneurial intentions of students in the Faculty of Health Sciences. The entrepreneurial intention for the students in the Faculty of Health Sciences is low because of the low scale mean of 2.08. This low entrepreneurial intention can be attributed to the fact that the students in this faculty do not have entrepreneurship and small business management as a course in their curriculum. This result is consistent with Ozaralli and Rivenburgh (2016) that found Turkish and US students have low entrepreneurial intentions to start businesses because of lack of entrepreneurial education and training.

Table 3 depicts the descriptive statistics of entrepreneurial intentions of students in the Faculty of Management and Law. The entrepreneurial intention for the students in the Faculty of Management and Law is high because of the high scale mean of 5.04. This high entrepreneurship intention can be attributed to the fact that the students in this faculty have entrepreneurship and small business management as a course in their curriculum. This result is consistent with Fatoki (2014) that found that business management students have high entrepreneurial intentions to start businesses.

TABLE 2: Entrepreneurial intentions of students in the Faculty of Health Sciences.

\begin{tabular}{lcc}
\hline Statement & Mean & Standard deviation \\
\hline $\begin{array}{l}\text { 'I am ready to do anything to become an } \\
\text { entrepreneur' }\end{array}$ & 1.48 & 0.505 \\
'My professional goal is to become an entrepreneur' & 2.16 & 0.889 \\
$\begin{array}{l}\text { 'I will make every effort to start and run my own } \\
\text { business' }\end{array}$ & 2.48 & 1.111 \\
'I am determined to create a business in the future' & 2.05 & 1.096 \\
'I have a serious thought of starting a-business' & 2.08 & 1.124 \\
$\begin{array}{l}\text { 'I have got a firm intention to start a business } \\
\text { someday' }\end{array}$ & 2.23 & 1.146 \\
\begin{tabular}{l} 
Scale mean \\
\hline
\end{tabular} & 2.08 & 0.98 \\
\hline
\end{tabular}

Source: Research Data 2018 
TABLE 3: Entrepreneurial intentions of students in the Faculty of Management and Law.

\begin{tabular}{lcc}
\hline Statement & Mean & Standard deviation \\
\hline $\begin{array}{l}\text { 'I am ready to do anything to become an } \\
\text { entrepreneur' }\end{array}$ & 5.34 & 1.425 \\
$\begin{array}{l}\text { 'My professional goal is to become an } \\
\text { entrepreneur' }\end{array}$ & 5.22 & 1.343 \\
$\begin{array}{l}\text { 'I will make every effort to start and run my } \\
\text { own business' }\end{array}$ & 5.66 & 1.267 \\
$\begin{array}{l}\text { 'I am determined to create a business in the } \\
\text { future' }\end{array}$ & 5.94 & 1.389 \\
$\begin{array}{l}\text { 'I have a serious thought of starting a-business' } \\
\text { 'I have got a firm intention to start a business } \\
\text { someday' }\end{array}$ & 5.76 & 1.278 \\
\begin{tabular}{l} 
Scale mean \\
\hline
\end{tabular} & 5.04 & 1.365 \\
\hline
\end{tabular}

Source: Research Data 2018

TABLE 4: Entrepreneurial intentions of students in the Faculty of Humanities.

\begin{tabular}{lcc}
\hline Statement & Mean & Standard deviation \\
\hline $\begin{array}{l}\text { 'I am ready to do anything to become an } \\
\text { entrepreneur' }\end{array}$ & 3.09 & 1.379 \\
$\begin{array}{l}\text { 'My professional goal is to become an } \\
\text { entrepreneur' }\end{array}$ & 3.06 & 1.217 \\
$\begin{array}{l}\text { 'I will make every effort to start and run my } \\
\text { own business' }\end{array}$ & 3.00 & 1.136 \\
$\begin{array}{l}\text { 'I am determined to create a business in the } \\
\text { future' }\end{array}$ & 3.10 & 1.096 \\
$\begin{array}{l}\text { 'I have a serious thought of starting a-business' } \\
\text { 'I have got a firm intention to start a business } \\
\text { someday' }\end{array}$ & 3.05 & 1.08 \\
\begin{tabular}{l} 
Scale mean \\
\hline
\end{tabular} & 3.06 & 1.240 \\
\hline
\end{tabular}

Source: Research Data 2018

Table 4 shows the descriptive statistics of entrepreneurial intentions of students in the Faculty of Humanities. The entrepreneurial intention for the students in the Faculty of Humanities is low because of the low scale mean of 3.06. This low entrepreneurship intention can be attributed to the fact that the students in this faculty do not have entrepreneurship and small business management as a course in their curriculum. This result is consistent with Ozaralli and Rivenburgh (2016) that found Turkish and US students have low entrepreneurial intentions to start businesses because of lack of entrepreneurial education and training.

Table 5 depicts the descriptive statistics of entrepreneurial intentions of students in the Faculty of Health Sciences. The entrepreneurial intention for the students in the Faculty of Science and Agriculture is low because of the low scale mean of 2.50. This low entrepreneurial intention can be attributed to the fact that the students in this faculty do not have entrepreneurship and small business management as a course in their curriculum. This result is consistent with Ozaralli and Rivenburgh (2016) that found Turkish and US students have low entrepreneurial intentions to start businesses because of lack of entrepreneurial education and training.

Table 6 presents the result of the Chi-square test on the entrepreneurial intention of students in the institution of higher education. The result shows that the probability value of $0.011(1.1 \%)$ is less than $5 \%$. Therefore, there are significant differences in the entrepreneurial intentions of students in the faculties of health sciences, management and law,
TABLE 5: Entrepreneurial intentions of students in the Faculty of Science and Agriculture.

\begin{tabular}{lcc}
\hline Statement & Mean & Standard deviation \\
\hline $\begin{array}{l}\text { 'I am ready to do anything to become an } \\
\text { entrepreneur' }\end{array}$ & 2.42 & 1.056 \\
$\begin{array}{l}\text { 'My professional goal is to become an } \\
\text { entrepreneur' }\end{array}$ & 2.57 & 1.156 \\
$\begin{array}{l}\text { 'I will make every effort to start and run my } \\
\text { own business' }\end{array}$ & 2.45 & 1.162 \\
$\begin{array}{l}\text { 'I am determined to create a business in the } \\
\text { future' }\end{array}$ & 2.36 & 1.065 \\
$\begin{array}{l}\text { I have a serious thought of starting a-business' } \\
\text { 'I have got a firm intention to start a business }\end{array}$ & 2.69 & 1.172 \\
$\begin{array}{l}\text { someday' } \\
\text { Scale mean }\end{array}$ & 2.49 & 1.098 \\
\hline
\end{tabular}

Source: Research Data 2018

TABLE 6: Chi-square tests.

\begin{tabular}{lccc}
\hline Variable & Value & df & $\begin{array}{c}\text { Asymptotic significance } \\
\text { (two-sided) }\end{array}$ \\
\hline Pearson Chi-square & $11.176^{*}$ & 3 & 0.011 \\
Likelihood ratio & 12.663 & 3 & 0.005 \\
Linear-by-linear association & 0.412 & 1 & 0.521 \\
No. of valid cases & 355 & - & - \\
\hline
\end{tabular}

Source: Research Data 2018

*, Significant at $5 \%$.

humanities and science and agriculture. This result implies that the alternative hypothesis could be accepted:

$\mathbf{H}_{\mathbf{a}} \mathbf{1}$ : Significant differences exist between entrepreneurial intentions of students in four different faculties: health sciences, management and law, humanities as well as science and agriculture.

\section{Conclusions and managerial implications}

Statistics South Africa (2018a) reported that the youth unemployment is on the rise and is currently high at $38.2 \%$. Encouraging students to start new businesses by creating employment opportunities for other youths can reduce the youth unemployment in South Africa. The youth is the entrepreneurs and leaders of tomorrow. The majority of students in South African universities fall into this age group of 18-35 years.

This study is guided by two objectives, firstly, to determine the entrepreneurial intention of students in four different faculties (health sciences, management and law, humanities as well as science and agriculture) in a historically disadvantaged South African university. Secondly, to assess if significant differences exist between entrepreneurial intentions of students in four different faculties (health sciences, management and law, humanities as well as science and agriculture) in a historically disadvantaged South African university. The study was quantitative in nature and used random sampling technique to ensure that all students have equal chances of being selected.

The study found a high entrepreneurial intention for the students in the Faculty of Management and Law and low entrepreneurial intention for the students in the other three faculties, namely, health sciences, humanities and science 
and agriculture. The high entrepreneurial intention in the Faculty of Management and Law was attributed to the entrepreneurial education in the faculty. The study also found that there are significant differences in the entrepreneurial intentions of students in the faculties of health sciences, management and law, humanities and science and agriculture. This result implies that the alternative hypothesis could be accepted:

$\mathbf{H}_{\mathbf{a}}$ : Significant differences exist between entrepreneurial intentions of students in four different faculties: health sciences, management and law, humanities as well as science and agriculture.

Aulia and Hadi (2018) pointed out that despite the growing debate on entrepreneurial intentions, extant studies fall short in addressing the entrepreneurial intentions of students across faculties in an institution of higher education. The novelty of this study is the contribution to the body of knowledge on entrepreneurial intentions of university students across faculties in South Africa. In addition, studies on entrepreneurial intentions of students from historically disadvantaged universities are underexplored. The study provides useful recommendations on entrepreneurial intention of South African students from a historically disadvantaged university perspective. The following recommendations are proposed based on the findings of the study.

\section{Department of Higher Education and Training and universities in South Africa}

Firstly, entrepreneurial education courses should be made compulsory for all students in the institution of higher education. This should provide entrepreneurial education for all students irrespective of their faculties. Secondly, policy decisions that support students to start businesses should be implemented by the Department of Higher Education and Training in all South African universities. This should increase the number of start-ups by university students irrespective of their faculties and create employment and economic development in South Africa. Thirdly, practical entrepreneurship can be stimulated in South African universities through projects such as business plan competitions. All universities should encourage students to develop, compete and present business plans to various funders. Furthermore, the students with the best business plans should be supported financially and non-financially by the universities, government agencies (Small Enterprise Finance Agency [SEFA], Small Enterprise Development Agency [SEDA], Industrial Development Corporation [IDC]) and financial institutions (ABSA, FNB, Standard Bank, Nedbank, Capitec). This should increase and foster the entrepreneurship spirit of university students in South Africa.

\section{Students}

Firstly, a shift in the mind of university students is needed. University students should see themselves as job creators instead of job seekers. Secondly, university students need to learn from entrepreneurs about the failures and successes of businesses. Thirdly, university students should learn practically through learnerships and internships programme. This practical experience will assist university students later on when they start their own businesses. Fourthly, university students should establish networks with entrepreneurs. Networking is a long-term investment and will allow the university students to meet entrepreneurs, potential investors and funders that can help university students to start their own businesses.

\section{Limitations}

The study focused on one historically disadvantaged university in South Africa; therefore, the findings of this study should be interpreted cautiously for other universities in South Africa. Future research can be replicated to students in other South African universities.

\section{Future research}

The study focused on one historically disadvantaged university in South Africa; therefore, the findings of this study should be interpreted cautiously for other universities in South Africa. Future research can be replicated in other South African universities.

\section{Acknowledgements}

The authors would like to acknowledge the valuable input from the statistician before the data collection.

\section{Competing interests}

The authors declare that they have no financial or personal relationships that may have inappropriately influenced them in writing this article.

\section{Authors' contributions}

O.O. wrote the paper and V.M. collected and coded the data.

\section{References}

Ajzen, I., 1991, 'The theory of planned behavior', Organizational Behavior and Human Decision Processes 50(2), 179-211. https://doi.org/10.1016/0749-5978(91) 90020-T

Aulia, P.A. \& Hadi, C., 2018, 'Attitude relationships with entrepreneurial intentions to students', Airlangga University, Surabaya.

Barral, M.R.M., Ribeiro, F.G. \& Canever, M.D., 2018, 'Influence of the university environment in the entrepreneurial intention in public and private universities', Revista de Administração 53(1), 122-133.

Fatoki, O., 2014, 'The entrepreneurial intention of undergraduate students in South Africa: The influences of entrepreneurship education and previous work experience', Mediterranean Journal of Social Sciences 5(7), 294. https://doi. org/10.5901/mjss.2014.v5n7p294

Fatoki, O. \& Chindoga, L., 2011, 'An investigation into the obstacles to youth entrepreneurship in South Africa', International Business Research 4(2), 161-169. https://doi.org/10.5539/ibr.v4n2p161

Fayolle, A. \& Gailly, B., 2015, 'The impact of entrepreneurship education on entrepreneurial attitudes and intention: Hysteresis and persistence', Journal of Small Business Management 53(1), 75-93.

Fayolle, A. \& Liñán, F., 2014, 'The future of research on entrepreneurial intentions', Journal of Business Research 67(5), 663-666. https://doi.org/10.1016/j.jbusres. 2013.11.024 
Feinberg, F., Kinnear, T. \& Taylor, J., 2012, Modern marketing research: Concepts, methods, and cases, Nelson Education, Scarborough, ON.

Gerba, D., 2012, 'Impact of entrepreneurship education on entrepreneurial intentions of business and engineering students in Ethiopia', African Journal of Economic and Management Studies 3(2), 258-277. https://doi.org/10.1108/20400701211265036

Global Entrepreneurship Monitor, 2018, Global Entrepreneurship Research Association viewed 28 April 2018, from https://www.gemconsortium.org/report/50012

Herrington, M. \& Kew, P., 2016, South African Report 2015/2016. Is South Africa heading for an economic meltdown, Development Unit for New Enterprise, University of Cape Town, Cape Town.

Iwu, C.G., Ezeuduji, I., Eresia-Eke, C. \& Tengeh, R., 2016, 'The entrepreneurial intention of university students: The case of a university of technology in South Africa' CEconomica 12(1), 164-181.

Levie, J., Hart, M. \& Anyadike-Danes, M., 2009, 'The effect of business or enterprise training on opportunity recognition and entrepreneurial skills of graduates and non-graduates in the UK', Frontiers of Entrepreneurship Research 29(23), 1.

Liñán, F. \& Chen, Y.W., 2009, 'Development and cross-cultural application of a specific instrument to measure entrepreneurial intentions', Entrepreneurship Theory and Practice 33(3), 593-617. https://doi.org/10.1111/j.1540-6520.2009.00318.x

Madzivhandila, T.S. \& Dlamini, M.S., 2015, 'Woman and youth owned enterprises in South Africa: Assessing the needs, opportunities \& challenges', in M.P. Sebola, R.M. Mkhonza, K.B. Dipholo, M.J. Mafunisa \& R.K. Manyaka (eds.), SAAPAM 4th Annual Conference Proceedings: Limpopo Chapter, 2015, pp.605-618, University of Limpopo Polokwane.

Malebana, M.J. \& Swanepoel, E., 2014, 'The relationship between exposure to entrepreneurship education and entrepreneurial self-efficacy', Southern African Business Review 18(1), 1-26.

Mganda, V.O., 2018, 'Viability of vibrant entrepreneurship to sustain economic growth in Tanzania towards middle-income status', Business Education Journal 2(1), 1-9.

Obembe, E., Otesile, O. \& Ukpong, I., 2014, 'Understanding the students' perspectives towards entrepreneurship', Procedia-Social and Behavioral Sciences 145, 5-11. https://doi.org/10.1016/j.sbspro.2014.06.005

Odora, R.J., 2015, 'Integrating product design and entrepreneurship education: A stimulant for enterprising design and engineering students in South Africa', Procedia Technology 20(1), 276-283. https://doi.org/10.1016/j.protcy.2015.07.044

Ozaralli, N. \& Rivenburgh, N.K., 2016, 'Entrepreneurial intention: Antecedents to entrepreneurial behavior in the USA and Turkey', Journal of Global Entrepreneurship Research 6(1), 3. https://doi.org/10.1186/s40497-016-0047-x
Palmer, J., Griswold, M., Eidson, V. \& Wiewel, P., 2015, 'Entrepreneurial intentions of male and female university students', International Journal of Business \& Public Administration 12(1), 152-166.

Pihie, Z.A.L. \& Akmaliah, Z., 2009, 'Entrepreneurship as a career choice: An analysis of entrepreneurial self-efficacy and intention of university students', European Journal of Social Sciences 9(2), 338-349.

Pihie, Z.A.L. \& Bagheri, A., 2013, 'Self-efficacy and entrepreneurial intention: The mediation effect of self-regulation', Vocations and Learning 6(3), 385-401. https://doi.org/10.1007/s12186-013-9101-9

Republic of South Africa, 2018, The Department of Higher Education and Training's 2018 Budget Vote, Government Printers, Pretoria.

Saroghi, H., Libaers, D. \& Burkemper, A., 2015, 'Examining the relationship between creativity and innovation: A meta-analysis of organizational, cultural, and environmental factors', Journal of Business Venturing 30(5), 714-731. https://doi. org/10.1016/j.jbusvent.2014.12.003

Scheepers, M.J., Solomon, G. \& de Vries, A., 2009, Entrepreneurial intentions and behaviour of South African university students. Global University entrepreneurial
spirit students' survey: South African report 2008-2009, University of spirit students survey: South African report 2008-2009, University of Stellenbosch, viewed n.d., from, http:/
SACountryReport_Final08_09.pdf

Shinnar, R.S., Giacomin, O. \& Janssen, F., 2012, 'Entrepreneurial perceptions and intentions: The role of gender and culture', Entrepreneurship Theory and Practice 36(3), 465-493. https://doi.org/10.1111/j.1540-6520.2012.00509.x

Singh, B., Verma, P. \& Rao, M.K., 2017, Influence of individual and socio-cultural factors on entrepreneurial intention, in M. Manimala and P. Thomas (eds.) Entrepreneurship Education, pp. 149-169, Springer, Singapore.

Statistics South Africa, 2018a, Youth unemployment is still high in Q2:2018, Government Printers, Pretoria.

Statistics South Africa, 2018b, Quarterly labour force survey QLFS Q2:2018, Government Printers, Pretoria.

Tomkins, N., 2012, 'The Youth Entrepreneurship Programme, NFTE: A qualitative exploration of the perspectives of participants and facilitators', Doctoral dissertation, School of Social Work and Social Policy, Trinity College Dublin.

Ubierna, F., Arranz, N. \& de Arroyabe, J.F., 2014, 'Entrepreneurial intentions of university students: A study of design undergraduates in Spain', Industry and Higher Education 28(1), 51-60. https://doi.org/10.5367/ihe.2014.0191

Zhang, P., Wang, D.D. \& Owen, C.L., 2015, 'A study of entrepreneurial intention of university students', Entrepreneurship Research Journal 5(1), 61-82. https://doi. org/10.1515/erj-2014-0004 